\title{
TANÜGYIgAZGATÁS GAZDASÁGI SZEREPLŐKKEL, A NÉMET SZAKKÉPZÉS PÉLDÁJA
}

\author{
FARKAS PÉTER
}

A német duális szakképzés piaci modell szerint működik. A gazdaság igényeinek megfelelő képzési kínálat biztosítását támogatja, hogy a duális képzésben nem az illetékes hatóságok és bizottságok, hanem a szakképzést felkínálók és elfogadók döntései határozzák meg a tanulószerződések szakmák szerinti megoszlását. A tanulók a vállalati munkahelyen folyó gyakorlati képzés keretében értéktermelő munkát is végeznek. A szakképzés vonzóerejének növelését, a hagyományos képzést választók arányának fenntartását a képzésbe bekapcsolódó fiatalok és fiatal felnőttek számára vonzó, a minimálbér szintjét elérő vagy meghaladó, ágazatonként és szakképesítésenként eltérő nagyságú tanulóbér biztosítja, amellyel elérhető, hogy a közepes és jó képességű tanulók megfelelő hányada az iskolai képzések helyett a duális képzési formát válassza. A tanulók által végzett munka értéke Németországban a felmérések szerint a képzési költségek kétharmadát-háromnegyedét fedezi. A tanulmány a német Szövetségi Szakképzési Intézet internetoldalán elérhető dokumentumok alapján bemutatja a duális szakképzés területén illetékes hatóságok, intézmények és szervezetek együttműködésének és tevékenységének szabályozását és intézményi kereteit.

Kulcsszavakः német szakképzés, duális képzés, tanulószerződés, német szakképzési törvény, tanulóbér, a szakképzés finanszírozása, Szövetségi Szakképzési Intézet, a képzés tartalmi szabályozása

The German dual vocational training system operates according to a market model. Promoting the supply of training to meet the needs of the economy is supported by the fact that, in dual education, it is not the decisions of the competent authorities and committees, but the decisions of vocational training providers and apprentices that determine the distribution of apprenticeships by profession. The apprentices also carry out valueadded work as part of the on-the-job training in the company workplace. Increasing the attractiveness of vocational training and maintaining the proportion of those opting for traditional training will ensure that young people and young adults in education receive attractive levels of pay equal to or above the minimum wage, differing across sectors and qualifications, choose dual training instead of school. The value of work done by students in Germany is estimated to cover two thirds to three quarters of the cost of training.

Levelező szerző: Farkas Péter. E-mail: farkas.peter11@gmail.com 
Based on documents available on the website of the German Federal Institute for Vocational Training, the study describes the rules and institutional frameworks for cooperation and activities between authorities, institutions and organizations competent in the field of dual vocational training.

Keywords: vocational training in Germany, dual training, apprenticeship, Vocational Training Act, student salary, financing of training, Federal Institute for Vocational Training, content regulation of the training

\section{A duális képzésről}

A duális képzés eredetileg a kézműiparban folyó tanoncképzés volt. A 19. században jelentek meg az első kezdeményezések a tanoncképzés iskolai oktatással történő támogatására, először vasárnapi iskolák, rajziskolák formájában, majd a tanoncok iskolai oktatásának kiépítésével, kötelezővé tételével.

A német duális képzésben a tanuló kettős jogviszonyban áll: a gyakorlati képzést végző vállalkozással képzési szerződést (Ausbildungsvertrag) köt, ugyanakkor a szakképző iskola tanulója. A tanuló a vállalati munkahelyen folyó gyakorlati képzés keretében értéktermelő munkát is végez, amiért tanulóbért kap. A gyakorlati képzés időaránya 70\%, heti 3-3,5 nap. A tanulóbér nagysága Németországban 2017-ben átlagosan 876 euro ${ }^{1}$ volt. A tanulók által végzett munka értéke a felmérések szerint a képzési költségek kétharmadát-háromnegyedét fedezte.

A munkaadók elsősorban olyan tanulókkal kötnek képzési szerződést, akik motiváltak, pályaválasztási döntésük megalapozott, képesek a szakma elsajátítására és a gyakorlati képzés során a munkavégzésre. Az értéktermelés feltétele az is, hogy a közismereti oktatás a képzési szerződés megkötése előtt lezáruljon. Ez azt jelenti, hogy a tanulók felkészítése a szakmatanulásra az alapfokú oktatás és az azt kiegészítő hídprogramok feladata, s NAT-típusú követelmények a duális képzésben nem érvényesíthetők. (Ugyanakkor több európai országban is találkozunk olyan képzési formákkal, amelyek lehetővé teszik az érettségire való felkészülést a tanulószerződéssel párhuzamosan. Ehhez azonban biztosítják a feltételeket, pl. a szakképző évfolyamok számának növelésével.)

Németországban jelenleg a felsőoktatásban továbbtanulók létszáma meghaladja a duális képzésbe továbblépők számát - 2017-ben 490 ezren léptek duális képzésbe, s 515 ezren a felsőoktatásba.

A német felső középfokú szakképzés három alapintézménye a duális képzés, az iskolai szakképzés és a közoktatás és szakképzés között müködő átvezető programok. Tekintettel a duális képzés magas bemeneti követelményeire, az elmúlt években a szakképző intézményrendszerbe belépő egymillió fős tömeg közel 30 százaléka az átvezető programokban, ötöde a tartományi hatáskörbe tartozó iskolai szakképzésben, $s$ fele a duális képzésben tanult tovább.

1 https://www.bibb.de/de/73539.php [Letöltve ez és valamennyi internetes hivatkozása: 2019. 10. 16.] 
A duális képzésbe lépés feltétele elvben a 9 vagy 10 osztályos tankötelezettség teljesítése, a belépők előképzettsége azonban nagyon differenciált. Az utolsó ismert adatok szerint 2016-ban a duális képzésbe lépők 3,8\%-a nem szerzett alapfokú iskolai végzettséget, 23,6\%-a a legalacsonyabb presztízsü, 9 vagy 10 évfolyamos Hauptschulevégzettséggel, 47,4\% 10 évfolyamos reáliskolai végzettséggel, 22,9\% érettségivel vagy más felsőoktatásba lépésre jogosító végzettséggel rendelkezett. ${ }^{2} \mathrm{~A}$ duális képzésben tanulók átlagéletkora meghaladja a 20 évet, ez azt jelenti, hogy a képzés elkezdésekor többségük 17-18 éves.

\section{A tanulószerződés keretében folyó képzés jellemzői}

A gyakorlati képzés meghatározó színhelye a vállalati munkahely. Az alapképzésben, illetve speciális technológiák oktatásában központi tanmühelyek, üzemek feletti képző helyek is szerepet játszanak. A gyakorlati képzés finanszírozása a gazdaság feladata. A magyarországi szakképzési alaphoz hasonló intézmény csak az építőiparban müködik, s a központi tanmühelyek fenntartásának költségeit, valamint a központi tanmühelyben és az iskolában töltött időre eső tanulóbért fedezi.

Életkoruk és előképzettségük alapján a tanulók értékes munkaerőnek tekinthetők, a képzési költségek kétharmadát megtermelik. (A munkaadók a képzési kiadások meghatározó részét a tanulók bérezésére fordítják.) A tanulóbér nagyságát ágazati tarifaszerződések határozzák meg, a bér minden évfolyamon növekedik, s nagyságát a keresleti és kínálati viszonyok is befolyásolják. Kiemelkedően magasak a tanulóbérek az építőiparban, egyes igényes fémipari és elektrotechnikai szakmákban, s alacsonyabbak a lányok által választott szolgáltató és kereskedelmi ágazatokban. Az utolsó képzési évben az építőipari tanulók 1500 eurót is meghaladó tanulóbért kapnak. ${ }^{3}$

A németországi szakmunkástanulót felnőttnek tekintik. Munkaideje a gyakorlati képzési napokon nyolc óra. Az iskolai oktatás időkereteit a tartományi oktatási miniszterek állandó tanácsának (Kultusministerkonferenz, KMK) 2019. szeptember 20-án módosított 2015. évi határozata szabályozza. ${ }^{4} \mathrm{~A}$ dokumentum szerint a szakiskolai oktatás heti 12 óra időtartamú. Szakmai elméleti és általános oktatásból áll. A szakmai elméleti oktatás időkerete általában nyolc óra, az általános, közismereti oktatásra heti 4 órát fordítanak. Az iskolában folyó oktatás a KMK által kiadott mintakerettantervekre épül, amelyeket a szakmai és vizsgakövetelményekkel össze kell hangolni. Az óratervek a kötelező sáv mellett kötelezően választható és/vagy választható sávot is elöírhatnak. Ezek a nyelvoktatás támogatására, elmélyítésére és bővítésére is használhatók. A közismereti és szakmai elméleti oktatást vagy blokkosított formában, vagy hetente váltakozó órarenddel szervezik: ekkor az egyik héten egy, a másikon két napot töltenek a tanulók az iskolában. A különböző ágazatokban azonban nagyon sokféle oktatásszervezéssel találkozhatunk. (Pl. heti három nap vállalati, heti két nap iskolai képzés.)

Bildung in Deutschland 2018. pp. 128-131. https://www.bildungsbericht.de/de/bildungsberichte -seit-2006/bildungsbericht-2018/pdf-bildungsbericht-2018/bildungsbericht-2018.pdf

3 https://www.berufsbildung-bau.de/ausbildung/infos-zur-ausbildung/

4 Rahmenvereinbarung über die Berufsschule (Beschluss der Kultusministerkonferenz vom 12. 03. 2015 i.d.F. vom 20. 09. 2019). https://www.kmk.org/fileadmin/veroeffentlichungen_beschluesse/2015/ 2015_03_12-RV-Berufsschule.pdf 
A kötelező iskolai oktatás időkeretének ismeretében meghatározható a gyakorlati képzés elvi időkerete is. A tanév negyven oktatási hétből áll. Az iskolai oktatás időkerete heti 1,5 nap, $40 \times 1,5=60$ nap $=12$ hét. A tanulók évi négy hét szabadságra jogosultak. A gyakorlati képzésre így az 52 hetes naptári évben tanévenként elvben 36 hét $\times 40$ óra marad, a három képzési évben összesen $3 \times 1440=4320$ óra.

A németországi duális képzésben oktatható kb. 320 államilag elismert szakképesítés szinte a teljes foglalkoztatási rendszert lefedi, a legegyszerübb építőipari, kereskedelmi vagy vendéglátóipari szakmáktól a Magyarországon a szakgimnáziumban vagy a felsőoktatásban oktatott kereskedelmi, pénzügyi, informatikai képesítésekig. ${ }^{5}$

\section{Illetékességek}

A szakképzés szervezésének, irányításának, működtetésének kereteit az 1969. évi Szakképzési törvény (Berufsbildungsgesetz) határozza meg. ${ }^{6}$

Németország szövetségi állam, 16 tartományból áll. Az iskolai oktatás szabályozása és müködtetése a tartományi kormányok hatáskörébe, a vállalati munkahelyeken folyó duális képzés szabályozása a szövetségi kormány illetékességébe tartozik.

A szakképzéspolitika alakítása a Szövetségi Oktatási és Kutatási Minisztérium (Bundesministerium für Bildung und Forschung, BMBF) feladata. ${ }^{7}$ A minisztérium elkészíti az éves szakképzési jelentést, szakképzésfejlesztési programokat kezdeményez és irányít, felügyeli a 2010 után megszüntetett magyar Nemzeti Szakképzési és Felnőttképzési Intézet partnerintézménye, a Szövetségi Szakképzési Intézet (Bundesinstitut für Berufsbildung, BIBB) tevékenységét.

Amint fent jeleztük, az iskolai oktatás a tartományi kormányzatok hatáskörébe tartozik. A tartományi oktatási intézmények közötti átjárhatóság, illetve az egységes követelmények biztosítása érdekében hozták létre a tartományi oktatási miniszterek állandó tanácsát, röviden Kultusministerkonferenz, ${ }^{8}$ amely évente 3-4 alkalommal ülésezik, s egyéb feladatai mellett a közoktatást és szakképzést végző iskolák számára ajánlásokat és mintatanterveket ad ki. A mintakerettantervek alapján készítik el a tartományi oktatási hatóságok, illetve a megfelelő háttérintézmény a kerettanterveket.

A felső középfokon folyó szakképzésben a duális modell a meghatározó. A duális képzésben államilag elismert szakképesítéseket oktatnak, egységes szakmai és vizsgakövetelmények szerint (Ausbildungsordnung). A szakmai és vizsgakövetelmény része a vállalati munkahelyeken folyó gyakorlati képzés keretterve (Ausbildungsrahmenplan). A gyakorlati képzést kiegészítő iskolai közismereti és szakmai elméleti oktatás a tartományi hatóságok által kiadott kerettantervek (Rabmenlebrplan) szerint folyik.

A duális szakképzés fejlesztésében és müködtetésében meghatározó szerepet játszanak a vállalkozások, a vállalkozások érdekvédelmi szervezetei, az állam és az iskolafenntartók. Az állam, a gazdaság és a képzés szereplőinek feladatait és együttmüködését a szakképzési törvény (Berufsbildungsgesetz) és a tartományi oktatási törvények szabályozzák.

\footnotetext{
Informationen zu Aus- und Fortbildungsberufen. https://www.bibb.de/de/berufeinfo,php

Berufsbildungsgesetz. http://www.gesetze-im-internet.de/bbig_2005/

https://www.bmbf.de/

https://www.kmk.org/
} 
Az 1969. évi, utoljára 2005-ben módosított német szakképzési törvény a duális képzés alapvető szabályzására korlátozódik. A képzés szervezésekor további jogszabályokat is figyelembe kell venni. Ezek közül a legfontosabbak: a kisipari képzésről szóló rendelet (Handwerksordnung), a szakoktatókkal szemben támasztott követelményeket összegző rendelet (Ausbilder-Eignungsverordnung), az ifjúsági munkavédelmi törvény (Jugendarbeitsschutzgesetz), az államilag elismert képesítések jegyzéke és a tanulószerződés-minta. A duális képzés keretfeltételeit a felsorolt jogszabályok együttesen fogalmazzák meg. A tanulók és a képző intézmények számára évente kiadják a szakképzésre vonatkozó jogszabályok gyüjteményét, amely elektronikus formában is elérhető. ${ }^{9}$

A hatályos német szakképzési törvény ${ }^{10}$ áttekintése után megállapítható, hogy a német duális rendszerben az állami és a munkaadói funkciók elválnak. A kamarák a vizsgáztatásért, a duális képzés nyilvántartásáért és ellenőrzéséért, a szakmai szervezetek a tartalmi fejlesztésért, az Oktatási és Kutatási Minisztérium az iskolában folyó oktatásért, a Szövetségi Szakképzési Intézet a fejlesztések koordinálásáért, menedzseléséért felel. A kamarák csak azon képzések területén illetékesek, amelyek tanulószerződés keretében folynak.

Az 1993-as magyar szakképzési törvény a német mintát követte. A magyar és a német szabályozás közötti legnagyobb különbség az, hogy míg a magyar szakképzési törvényben az iskolai rendszerű szakképzésre helyezik a hangsúlyt, s a tanulószerződés keretében folyó képzés az iskolai rendszerü képzés egyik lehetséges formája, ${ }^{11}$ addig a német törvény elkülöníti a tanulószerződés keretében folyó és az iskolai rendszerű szakképzést.

A németországi „üzemi szakképzés” (betriebliche Berufsbildung) a gazdaság üzemeiben, s ezzel összevethető intézményekben, közintézményekben, a „szabad foglalkozást gyakorló" munkaadóknál, illetve háztartásokban folyik. Az iskolai közismereti oktatás és szakmai elméleti és a szakmai elméleti oktatással összehangolt, korlátozott időtartamú iskolai gyakorlati képzés a szakképző iskolában, az egyéb képzések az „üzemen kívüli képzés" intézményeiben folyhatnak. Lehetőség van az intézmények együttműködésére is. $(2 . \S)$

A szakképzési törvény hatáskörébe azok a képzések tartoznak, amelyek nem tartoznak

- a tartományi iskolai törvények hatáskörébe,

- a felsőoktatási intézmények hatáskörébe,

- a közszolgálat területére,

- a nemzetközi kereskedelmi hajózás körébe.

A kézmüipar területén a Kisipari törvény határozza meg a szakképzés feltételeit, amely azonban a szakképzési törvény számos szakaszát betű szerint átveszi. (3. §)

A német szakképzési törvény további szakaszai a magyarországihoz hasonló formában szabályozzák az ifjúsági szakképzés körét (18 évesnél fiatalabb személyek csak államilag elismert szakmában képezhetők), az államilag elismert szakképzés időbeli ke-

\footnotetext{
9 Ausbildung und Beruf Rechte und Pflichten während der Berufsausbildung. https://www.bmbf.de/ upload_filestore/pub/Ausbildung_und_Beruf.pdf

10 http://www.gesetze-im-internet.de/bbig_2005/

11 1993, évi LXXVI. törvény a szakképzésről, 15. § (3) bekezdés, közlönyállapot. https://mkogy.jogtar.hu/ jogszabaly?docid=99300076.TV
} 
reteit, a szakmajegyzékbe történő felvétel szabályait, a szakmai és vizsgakövetelmények kiadásának eljárásrendjét és tartalmi elemeit, az új szakképesítések kísérleti kipróbálásának lehetőségeit és a szakmai előképzettség beszámításának szabályait. Pontosan szabályozott a képzési idő lerövidítésének és esetleges megnövelésének lehetősége. (Ez az érettségihez vagy a szakmai előképzettség beszámításához kapcsolható.) Figyelemre méltó az a gyakorlat, amely sikertelen szakmai vizsga után a tanulót nem taszítja ki az oktatásból, hanem lehetővé teszi a tanulószerződés meghosszabbítását egy évvel, a szakmai vizsga megismétléséig.

A szakképzési törvény második fejezete nagyon részletesen szabályozza a tanulószerződést, a tanulószerződés tartalmi elemeit, a tanuló kötelezettségeit, juttatását, a képző kötelezettségeit. A harmadik fejezet a képzést folytató vállalkozásokkal és a képzést végző személyekkel szemben támasztott követelményeket fejti ki.

A törvény több kérdésben rendezi az egyeztetés feltételeit a Szövetségi Gazdasági és Technológiai Minisztérium vagy az illetékes ágazati minisztérium, illetve a Szövetségi Oktatási és Kutatási Minisztérium között.

A magyar szabályozásban kiemelt szerepet játszik a Kereskedelmi és Iparkamara. Németországban a képzést folytató vállalkozások és a képzést végző személyek alkalmasságát, szakmai hatósági ellenőrzését „az illetékes helyek” látják el. (32. §) Magyarul nagyon nehezen értelmezhető, túl általános az „illetékes hely” (zuständige Stelle) megfogalmazás. Miután az adott körbe tartozó meghatározó intézmények (71. §) az Ipari és Kereskedelmi Kamara (Industrie- und Handelskammer), a Kézmüves Kamara (Handwerkskammer) és a Mezőgazdasági Kamara (Landwirtschaftskammer), javasolható a kamarák fogalom használata. A jog területén a megfelelő ügyvédi, jegyzői, szabadalmi jogászi kamarák, a könyvvizsgálat és adótanácsadás területén a megfelelő kamarák, az egészségügyi szakalkalmazottak egészségügyi szakképzése területén az orvosi, fogorvosi, állatorvosi és gyógyszerészkamarák illetékesek. Ha olyan területen folyik képzés, ahol nincs megfelelő illetékes kamara, a tartomány jelöl ki „illetékes helyet” a képzés felügyeletére.

A németországi kamarák jogilag egyenrangú intézmények. Központi szervezeteik és regionális, tartományi szervezeteik honlapjairól részletes információk szerezhetők. ${ }^{12}$ Feladataik ellátására nagyon hatékony háttérintézményeket tartanak fenn, mint pl. az Ipari és Kereskedelmi Kamara (Industrie- und Handelskammer) vizsgafeladat-fejlesztő intézetei ${ }^{13}$ vagy pedagógiai módszertani szolgáltató háttérintézményei.

\section{A kamarák feladatai}

A szakképzési törvény szerint a németországi kamarák feladatai a szakképzési szerződések nyilvántartása, ellenőrzése területén hasonlóak a magyarországi szabályozásban foglaltakhoz. A tanulószerződéseket és vizsgákat a regionális kamarai intézmények tartják nyilván. (Szakképzési Törvény, 34-36. §)

A kamarák legfontosabb feladatai a vizsgák szervezése, a vizsgabizottságok felállítása, a vizsgák lebonyolítása. A vizsgabizottság legalább három főből áll, tagjai a munkaadók, a munkavállalók és az iskola képviselői. A vizsgabizottság elnököt választ. A

12 http://www.dihk.de/themenfelder/aus-und-weiterbildung, http://www.zdh.de/bildung.html

13 http://www.ihk-aka.de/, http://www.ihk-zpa.de/, https://www.stuttgart.ihk24.de/pal 
vizsgáztatók nem kapnak díjazást, indokolt esetben költségtérítésben részesülnek. (37-41. §) A kamarák végzik a mestervizsgák szervezését, végrehajtását is, $s$ az általuk fenntartott továbbképző intézmények meghatározó szerepet játszanak a mesterképzés szervezésében.

Még egyszer tekintsük át a kompetenciákat: a német rendszerben az állami és a munkaadói funkciók elválnak. A kamarák a vizsgáztatásért, a duális képzés nyilvántartásáért és ellenőrzéséért, a szakmai szervezetek a tartalmi fejlesztésért, az Oktatási és Kutatási Minisztérium az iskolában folyó oktatásért, a Szövetségi Szakképzési Intézet a fejlesztések koordinálásáért, menedzseléséért, a kutatásért és a szakképzésipolitika szereplőinek érdekegyeztetéséért felel. A kamarák csak azon képzések területén illetékesek, amelyek tanulószerződés keretében folynak. Az iskolai oktatás a duális rendszerben is állami kompetenciába tartozik.

A németországi duális szakképzés fejlesztését, müködtetését segíti a Szövetségi Szakképzési Intézet, a Bundesinstitut für Berufsbildung.

$\mathrm{A} z$ intézet honlapján ${ }^{14}$ a németországi szakképzésre vonatkozó információk jelentős része elérhető. Folyamatos feladatainak egyike a szakmajegyzék gondozása és a fejlesztés menedzselése. Évente általában legfeljebb húsz-huszonöt vizsgakövetelményt adnak ki. 2018-ban mindössze 12 új szakmai és vizsgakövetelményt és egy kísérleti szakmai és vizsgakövetelményt jelentettek meg. A szakmai és vizsgakövetelmény kiadásával egyidejüleg mindig kiadják a gyakorlati képzésre vonatkozó kerettervet és az iskolai oktatáshoz szükséges mintakerettantervet. A követelmény hatályba lépésekor a megfelelő tankönyvek is rendelkezésre állnak. A hatályos dokumentumok a BIBB honlapján is elérhetők. A honlapon a megfelelő oldalon ${ }^{15}$ kiválaszthatunk egy szakképesítést - pl. az asztalos, Tischler szakképesítést, ${ }^{16} \mathrm{~s}$ a megnyíló oldalon a képesítésre és a képzésre, illetve az adott képesítés internetoldalán a képzés megszervezésére vonatkozó átfogó információkat is találunk. Utóbbi dokumentum egy másik oldalról is letölthető. ${ }^{17}$

\section{Döntéselőkészités}

A Szövetségi Szakképzési Intézet döntés-elökészítő, döntéshozó szerve a Főbizottság (Hauptausschuss). Tagjai a munkaadók, a munkavállalók, a tartományok nyolc-nyolc és a Szövetség öt képviselője. A munkaadók, munkavállalók képviselőit a kamarák és a munkaadói és munkavállalói szervezetek javaslatára négy évre az oktatási és kutatási miniszter nevezi ki. (92. §) A Főbizottság feladatai:

- döntéshozatal az Intézet ügyeiben

- tanácsadás a Szövetségi Kormány számára a szakképzés alapkérdéseiben

- az éves kutatási terv elfogadása

- állásfoglalás kiadása az éves szakképzési jelentéshez

- állásfoglalás az intézet által elkészített rendelettervezetekkel kapcsolatban

14 https://www.bibb,de/de/die_themen.php

15 https://www.bibb.de/de/berufeinfo.php

16 https://www.bibb.de/de/berufeinfo.php/profile/apprenticeship/n7865435

17 Ausbildung gestalten: Tischler/Tischlerin. Bundesinstitut für Berufsbildung (C) W. Bertelsmann Verlag GmbH \& Co. KG Bielefeld 2. Auflage 2009. https://www.bibb.de/veroeffentlichungen/de/publication/ show/1971 
A Szövetségi Szakképzési Intézet munkájának felügyeletét a Szövetségi Oktatási és Kutatási Minisztérium látja el.

\section{Kutatásfejlesztés}

A BIBB törvényben meghatározott feladatai közül érdemes kiemelni a szakképzéskutatást és -fejlesztést, illetve a tanácsadási és szolgáltatási feladatokat. Néhány kiemelt kutatási súlypont

- a szakképzési piac és a foglalkoztatási rendszer;

- a szakképzés korszerüsítése és minőségének fejlesztése;

- élethosszig tartó tanulás, a képzési utak átjárhatósága és egyenértékűsége;

- speciális célcsoportok szakmai képzése;

- a szakképzés nemzetközivé válása.

\section{A szakképzés tervezése}

A képzési létszámok tervezése a duális szektorban a német álláspont szerint nem indokolt. A Szövetségi Munkaügyi Ügynökség Munkaerőpiac- és Szakképesítés-kutató Intézetének igazgatója, dr. Joachim Möller 2007 elején egy interjúban kifejtette, hogy nem törekednek arra, hogy a tanulók szakmaválasztását vagy a képzési kínálatot befolyásolják. Ez a piac dolga. Ha van a piacon munkaerő iránti igény, akkor ez a képzési kínálatban tükröződik, és a gazdaság a vonzó bérekkel és a vonzó képzési feltételekkel befolyásolja a tanulók döntését. ${ }^{18}$

$\mathrm{Az}$ iskolai szektorban - ideértve a szakképző iskolákat is - a tartományi oktatási törvények szerint a fenntartók oktatásfejlesztési terveket készítenek. Például ÉszakRajna-Vesztfália tartományban a szakképző iskolák (Berufskollegs) fenntartói a járások (Kreis) és a járási jogú városok. Észak-Rajna -Vesztfáliában a járások lakossága általában hasonló nagyságú, mint a magyarországi megyéké, területük azonban sokkal kisebb. Fenti tartományi oktatási törvény ${ }^{19}$ szerint - 80. $\$(5)$ - az oktatásfejlesztési terveknek figyelembe kell venniük a jelenlegi és a jövőben várható iskolakínálatot - iskolatípusok, iskolaméretek, osztálylétszámok, képzési helyszínek szerint -, a tanulólétszám középtávú alakulását, az iskolaválasztási szándékokat és az ebből adódó iskolatípusok szerint várható tanulólétszámot s a férőhelykínálat középtávon várható alakulását.

\section{Finanszírozás}

A németországi duális képzésben a szakmunkásképző iskolában folyó szakmai elméleti és közismereti képzés költségeit a tartományi költségvetés és a fenntartó önkormányzat, a vállalati gyakorlati oktatás költségeit a munkaadó fizeti. Az iskolai költségek közül a tartomány a tanfelügyelet, a tantervfejlesztés, a tanárképzés- és továbbképzés és a pedagógusbérek stb. fedezetét biztosítja, míg a fenntartó önkormányzat az iskolaépület létesítéséért, felújításáért, fenntartásáért és az oktatás tárgyi feltételeiért felel.

18 Dem Fachkräftemangel mit mehr Anstrengungen in Bildung begegnen Interview mit Prof. Dr. Joachim Möller, BWP 2008/3. http://www.bibb.de/veroeffentlichungen/de/bwp/show/id/1708

19 Schulgesetz für das Land Nordrhein-Westfalen. https://www.schulministerium.nrw.de/docs/Recht/ Schulrecht/Schulgesetz/index.html, https://bass.schul-welt.de/6043.htm 
A z üzemek feletti képzőhelyek fenntartásában együttműködik a Szövetségi Kormány - az Oktatási és Kutatási Minisztérium -, a tartományi költségvetés és a Szövetségi Munkaügyi Ügynökség.

Németországban ténylegesen a gazdaság viseli a gyakorlati képzés költségeit. A munkaadók a képzési kiadások meghatározó részét a tanulók bérezésére fordítják. A tanulók, mint fent már idéztük, a ráfordítások kétharmadát megtermelik.

\section{Szakképzési alap}

Németországban a hetvenes évek második felében kísérletet tettek egy szakképzési alap létrehozására. Ez a kísérlet néhány éves huzavona után az alkotmánybíróságon elbukott. Egy ágazatban, az építőiparban azonban fennmaradt a szakképzési alap, amelyet ma elsősorban a központi képzőhelyek fenntartására és a központi képzőhelyen folyó képzés idejére eső tanulóbér finanszírozására fordítanak.

A német építőipari vállalatok a bértömeg meghatározott százalékát befizetik az építőipar bérkiegészítő és szabadságfedezeti pénztárába. A befolyó pénzből a tarifaszerződésben meghatározott keretek között a képző vállalkozások visszaigényelhetik a képzéssel kapcsolatos költségeket, így pl. a tanműhelyben folytatott képzés idejére járó tanulóbért.

Egy véletlenszerűen kiválasztott tartományban, Észak-Rajna-Vesztfáliában az építőiparban tanulószerződéssel rendelkező tanulók az első szakképzési évben 20 hetet, a másodikban 13 hetet, a harmadikban 4 hetet dolgoznak a központi tanmühelyben. ${ }^{20}$ $\mathrm{A} z$ építőipari szakmákat tanuló tanoncok esetében a munkaadók az első képzési évben tíz hónapra, a második képzési évben hat hónapra, a harmadik képzési évben egy hónapra járó tanulóbért igényelhetnek vissza. ${ }^{21} \mathrm{~A}$ visszatérítés magas mértéke azt tükrözi, hogy az első képzési évben a tanulótól nem várják el, hogy a munkahelyen értéket hozzon létre. A szabályozás a többi tartományban is nagyon hasonló.

\section{Összegzés, következtetések, kitekintés}

A duális képzés az általában elterjedt vélekedések szerint azt jelenti, hogy a képzés két helyszínen, az iskolában és a vállalati munkahelyen zajlik. Ténylegesen azonban ennél sokkal több: olyan szabályozott piaci modell, amely pontosan rögzíti a képzésben részt vevő munkaadók, tanulók, munkaadószervezetek, állami és önkormányzati szervezetek jogait, feladatait, együttműködésük kereteit és intézményi feltételeit. Az 1969-ben elfogadott német szakképzési törvény idézett paragrafusainak többsége évtizedek óta változatlan, esetleg az illetékes minisztériumok neve változott meg néhány alkalommal.

A folyamatosság nemcsak a jogszabályok, de például a szakmarendszer fejlesztése területén is jellemző. A múlt század harmincas éveiben kiadott szakmai és vizsgakövetelmények gyakran negyven-ötven évig hatályban maradtak, s nemcsak olyan hagyományos kézmüvesmesterségek esetében, mint pl. a nyerges vagy kötélverö, de olyan

20 Ausbildungsprogramm Stufenausbildung. https://www.berufsbildung-bau.de/ausbildung/ausbildungsprogramm/?tx_bfwseminar_seminarliste\% $5 \mathrm{Bk}$ ategorie $\% 5 \mathrm{D}=108 \mathrm{tx}$ _bfwseminar_seminarliste $\% 5$ Baction\%5D=show\&tx_bfwseminar_seminarliste\%5Bcontroller\%5D=Kategorie

${ }^{21}$ Finanzierung. https://www.berufsbildung-bau.de/ausbildung/infos-zur-ausbildung/finanzierung/ 
szélesebb körben oktatott szakmáknál is, mint a kőműves, ács vagy az üveges szakma. ${ }^{22}$ Ezt az tette lehetővé, hogy a szakmai és vizsgakövetelményekben a technológiai lépésekre és a felhasznált anyagokra vonatkozó információkat nagyon általános formában fogalmazták meg.

A német duális képzés fejlesztésekor a szakszerüség követelményeit is érvényesítették. Jó példa erre a Szövetségi Szakképzési Intézet. Az 1969. évi szakképzési törvény elfogadása után 1970-ben először a Szövetségi Szakképzéskutató Intézet jött létre, amely alapkutatásokat végzett és a kutatások keretében „kiképezte” a hetvenes évek második felében megalapított Szövetségi Szakképzési Intézet munkatársait, és kidolgozta a fejlesztés eszközrendszerét és módszertanát.

A duális képzés évtizedekig monopolhelyzetben volt a német munkaerőpiacon. $\mathrm{Az}$ elmúlt évtizedekben lassan elindult a tanulószerződést választók arányának csökkenése, s ma már magasabb a felsőoktatást választó fiatalok száma a hagyományos képzést választók számánál. ${ }^{23} \mathrm{~A}$ duális képzés jövőbeli változásai a munkaerő iránti követelmények módosulásától, a duális képzés vonzóerejének megőrzésétől és a demográfiai feltételektől függenek. A következő évtizedekben folyamatosan csökken az oktatási rendszerből kilépők létszáma, s egyes ágazatokban a munkaadók továbbra is arra törekedhetnek, hogy már a képzés során megnyerjék maguknak a tehetséges fiatalokat.

A duális képzés fenntartását és fejlesztését Németországban a következő funkcionális eszközök segítették:

A szakképzés vonzóerejének növelését, a hagyományos képzést választók arányának fenntartását a képzésbe bekapcsolódó fiatalok és fiatal felnőttek számára vonzó, a minimálbér szintjét elérő vagy meghaladó, ágazatonként és szakképesítésenként eltérő nagyságú tanulóbér biztosítja, amellyel elérhető, hogy a közepes és jó képességủ tanulók megfelelő hányada az iskolai képzések helyett a duális képzési formát válassza.

A gazdaság igényeinek megfelelö képzési kinálat biztositását segíti, hogy a duális képzésben nem az illetékes területi bizottságok, hanem a tanulószerződést felkínálók és elfogadók döntései határozzák meg a tanulószerződések szakmák szerinti megoszlását. A német szakemberek szerint a vállalati és tanulói döntések jobban leképezik a tényleges igényt, mint a más szempontokat is mérlegelő bizottsági kompromisszumok.

A gyakorlati képzés költségeinek csökkentését segiti, hogy a duális képzésben a tanulók a munkaadók képzési költségeinek jelentős részét, kétharmadát-háromnegyedét megtermelik. A képző vállalatok számára további költségmegtakarítást jelent, hogy a kiképzett tanulók közül a legjobbakat tovább foglalkoztatják, így az új munkaerő felkutatásának, megnyerésének, szükséges betanításának vagy a munkaszervezetbe való beilleszkedésének jelentős költségeit is megtakarítják. Az állam képzési kiadásai a viszonylag alacsony időarányú iskolai programokra, az iskolai hídprogramokra, a halmozottan hátrányos helyzetű fiatalok integrációját segítő programokra korlátozódnak.

22 Genealogie Sattler/-in (Hw, IH). https://www.bibb.de/de/berufeinfo.php/genealogy/tz564534 Genealogie Seiler/-in (Hw.) https://www.bibb.de/de/berufeinfo.php/genealogy/1211007 Genealogie Maurer/-in (Hw). https://www.bibb.de/de/berufeinfo.php/genealogy/4410301_ Genealogie Zimmerer/-in (Hw). https://www.bibb.de/de/berufeinfo.php/genealogy/4510401_ Genealogie Dachdecker/-in (Hw). https://www.bibb.de/de/berufeinfo.php/genealogy/12112013 Genealogie Glaser/-in (Hw), https://www.bibb.de/de/berufeinfo.php/genealogy/5646879

23 Bildung in Deutschland 2018. pp. 128-131. https://www.bildungsbericht.de/de/bildungsberichteseit-2006/bildungsbericht-2018/pdf-bildungsbericht-2018/bildungsbericht-2018.pdf. 
A duális képzés lehetövé teszi a gazdaság aktuális igényeinek megfelelö, versenyképes szakképzés megvalósitását. A duális képzésben a gyakorlati oktatás a termelő munkahelyeken is folyhat, ahol a tanulók megismerik a munkahelyi követelményeket, s a szakmai végzettség megszerzése után teljes értékű munkaerőként tudnak belépni a munkaerőpiacra. Miután a német munkaerőpiacon csak a korszerü technológiát hatékonyan alkalmazó vállalkozások versenyképesek, a tanulók a duális képzésben azokat a technológiákat is megismerik, amelyeket az iskolai tanmühelyekben nem lehet biztosítani.

A duális képzés pedagógiai eszközrendszerének fejlesztését szakszerüen segitik az illetékes hatóságok által fenntartott intézmények, a munkaadó szervezetek szakmai háttérintézményei, a Szövetségi Szakképzési Intézet, a szövetségi szintű oktatási kormányzat által koordinált nemzeti és európai forrásokból finanszírozott projektek, s a tartományi fenntartású továbbképző intézmények, illetve a felsőoktatásban müködő vagy más forrásokból támogatott kutató és fejlesztő intézetek.

A német duális szakképzés általában jó feltételek között müködik, programjaik, tanterveik, tankönyveik, a gyakorlati képzést segítő útmutatók, a pedagógus-továbbképzés igényes és számos területen modellértékü. Közvetlen átvételét azonban Magyarországon megnehezítik az eltérő feltételek, a képzésben részt vevő tanulók alacsonyabb életkora és alacsonyabb általános képzettsége, így a tanulóktól nem várható olyan értéktermelő munka sem, amely lehetővé tenné a magasabb juttatásokat. A magyar szakmunkásképzés csak nevében duális, finanszírozásában a tanulók által megtermelt érték alig játszik szerepet.

A német szakképzés fejlesztésére a folyamatosság a jellemzö. Az eltérö feltételek miatt lehet, hogy a németországi tapasztalatok rövid távon csak korlátozott körben hasznosíthatók, elsősorban talán az érettségizett fiatalok duális szakmai képzésében. Ugyanakkor azonban a német szakképzéskutatás és -fejlesztés tapasztalatai és produktumai a közvetlen hasznosíthatóságtól függetlenül fontos forrásokat jelentenek a szakképzéskutatás és -fejlesztés minden szereplője számára. ${ }^{24}$

24 BIBB: Die Themen im Überblick. https://www.bibb.de/de/die_themen.php

A cikk a Creative Commons Attribution 4.0 International License (https://creativecommons.org/licenses/ by/4.0/) feltételei szerint publikált Open Access közlemény, melynek szellemében a cikk bármilyen médiumban szabadon felhasználható, megosztható és újraközölhető, feltéve, hogy az eredeti szerző és a közlés helye, illetve a CC License linkje és az esetlegesen végrehajtott módosítások feltüntetésre kerülnek. (SID_1) 